\title{
GAMBARAN PERILAKU MEROKOK PADA MAHASISWA FAKULTAS KESEHATAN MASYARAKAT (FKM) DI KAMPUS XXX
}

\section{A Snapshot of the Behavior Smoked on a Student Faculty of Public Health on Campus $\boldsymbol{X X X}$}

\author{
Hilda Irianty, Ridha Hayati \\ Universitas Islam Kalimantan MAB Banjarmasin \\ (Hildanafarin@gmail.Com,085251150724)
}

\begin{abstract}
ABSTRAK
Menurut World Health Organization (WHO), tembakau membunuh lebih dari 5 juta orang per tahun dan diproyeksikan akan membunuh 10 juta orang sampai tahun 2020, dari jumlah itu 70\% korban berasal dari negara berkembang yang didominasi oleh kaum laki-laki sebesar 700 juta terutama di Asia. ASEAN merupakan sebuah kawasan dengan $10 \%$ dari seluruh perokok dunia dan $20 \%$ penyebab kematian global akibat tembakau. Persentase perokok pada penduduk di negara ASEAN tersebar di Indonesia (46,16\%).Tujuan dari Penelitian ini adalah untuk mengetahui gambaran perilaku merokok pada mahasiswa FKM di kampus XXX. Metode penelitian ini menggunakan penelitian deskriftip kuantitatif. Dimana hasil penelitian ini menggambarkan hasil perilaku merokok pada mahasiswa FKM yang ada di kampus XXX. Populasi dalam penelitian ini seluruh mahasiswa Fakultas Kesehatan Masyarakat yang ada dikampus Banjarbaru berjumlah 120 mahasiswa dan penentuan sampel menggunakan accidental sampling dengan jumlah sampel 54 orang. Hasil penelitian alasan pertama kali merokok responden yang paling dominan adalah penasaran atau coba-coba. Lebih dari separo responden perilaku merokoknya masuk dalam tipe perokok ringan. Dari 54 responden sebanyak 38 responden faktor yang mempengaruhi merokok adalah pengaruh dari teman. Disarankan kepada dinas terkait untuk menerapkan kebijakan Kawasan Tanpa Rokok (KTR) dan larangan merokok.
\end{abstract}

\section{Kata Kunci : Perilaku merokok, mahasiswa FKM}

\section{ABSTRACT}

According to world health organization (WHO), Tobacco killing more than 5 million people every year and projected kill 10 million people until 2020, $70 \%$ victims are from the developing country dominated by the man of 700 million especially in asia. Asean caused with 10 $\%$ from around the world smokers and $20 \%$ global death due to tobacco. The percentage smokers to those in asean countries is spread across indonesian (46,16\%). The purpose of this research is to know an image of smoking behavior of college students in public health faculty on campus xxx. A method of was used in this research is deskriptive quantitative research. The result of this research is an interpretation of respondens behaviour. The population in this research is the whole student of public health faculty which totaled 120 student and the researcher used Accidental Sampling to determine the sample 54 students chose as sample. Based on the result, respondens curiosity on cigarette is the first reason why they try to smoke. More than half of respondents, behavior smoking is classified as light smokers. 38 respondens revealed that they are smoke because of their friends influence. Hopefully the researcher suggested to apply no Smoking Area Policies (KTR) and smoking prohibition.

Keywords: Behavior smoking, students fkm 



\section{PENDAHULUAN}

Menurut World Health Organization (WHO), tembakau membunuh lebih dari 5 juta orang per tahun dan diproyeksikan akan membunuh 10 juta orang sampai tahun 2020, dari jumlah itu $70 \%$ korban berasal dari negara berkembang yang didominasi oleh kaum laki-laki sebesar 700 juta terutama di Asia. WHO memperkirakan 1,1 miliar perokok dunia berumur 15 tahun ke atas yaitu sepertiga dari total penduduk dunia. Indonesia menduduki peringkat ke-5 dalam konsumsi rokok di dunia setelah China, Amerika Serikat, Jepang dan Rusia (Wartonah, dkk, 2010). ${ }^{1}$ ASEAN merupakan sebuah kawasan dengan $10 \%$ dari seluruh perokok dunia dan $20 \%$ penyebab kematian global akibat tembakau. Persentase perokok pada penduduk di negara ASEAN tersebar di Indonesia $(46,16 \%)$, Filipina $(16,62 \%)$ Vietnam (14,11\%), Myanmar(8,73\%), Thailand (7,74\%), Malaysia (2,90\%), Kamboja (2,07\%), Laos (1,23\%), singapura $(0,39 \%)$, dan Brunei $(0,04 \%)$. (Kemenkes,RI.2013). ${ }^{2}$

Rata-rata perilaku merokok di Indonesia saat ini sebesar (29,3\%). Proporsi perokok terbanyak terdapat di Kepulauan Riau dengan jumlah perokok setiap hari $(27,2 \%)$ dan untuk proporsi perokok di Kalimantan Selatan setiap hari berjumlah $(22,1 \%)$. Dapat diketahui bahwa trend usia merokok meningkat pada usia remaja, yaitu pada kelompok umur 10-14 tahun dan 15-19 tahun. Hasil Riskesdas pada tahun 2007,2010, dan 2013 menunjukkan bahwa usia merokok pertama kali paling tinggi adalah pada kelompok umur 15-19 tahun. Sedangkan Proporsi terbanyak perokok aktif setiap hari pada umur 30-34 tahun sebesar 33,4\% dan umur 35-39 tahun sebesar $32,2 \%$ yang merupakan penduduk usia produktif (Kemenkes RI,2013). ${ }^{2}$

$$
\text { Menurut (Wismanto,2007) }{ }^{3} \text {, }
$$

Perilaku merokok merupakan masalah yang berkaitan dengan kesehatan masyarakat karena dapat menimbulkan berbagai penyakit bahkan dapat menyebabkan kematian baik bagi perokok dan orang yang ada disekitarnya (perokok pasif). Setiap orang telah mengetahui bahwa merokok adalah berbahaya bagi kesehatan, namun pada kenyataanya perilaku merokok masih sangat sulit untuk dikendalikan.

Menurut Wartonah, dkk (2010) ${ }^{1}$, faktor-faktor yang mempengaruhi kebiasaan merokok adalah tekanan teman sebaya, berteman dengan perokok usia muda, status sosial ekonomi rendah, mempunyai orang tua yang merokok, saudara kandung, lingkungan sekolah (guru) yang merokok dan tidak percaya bahwa merokok mengganggu kesehatan. Penelitian lain di Indonesia dilakukan oleh Global Tobacco Youth Survey (GTYS) atau survei merokok pada remaja di Jakarta menunjukkan perilaku merokok karena lingkungan keluarga $(66,85 \%)$ tinggal dengan keluarga yang merokok dan $(93,2 \%)$ karena faktor media atau melihat iklan rokok di media.

Studi pendahuluan yang dilakukan kepada 26 mahasiswa FKM melalui angket dan wawancara tentang perilaku merokok 
dari 26 mahasiswa tersebut hanya ada beberapa yang tidak pernah merokok dan sebagian masih merokok. Sebenarnya di FKM sudah menerapkan/mewajibkan mahasiswanya tidak merokok pada saat wawancara seleksi penerimaan mahasiswa FKM. Tetapi dilapangan masih ada yang ketahuan merokok dilingkungan kampus maupun diluar kampus. Tujuan penelitian untuk mengetahui Gambaran Perilaku Merokok Pada Mahasiswa Fakultas Kesehatan Masyarakat (FKM) di Kampus XXX”.

\section{BAHAN DAN METODE}

Jenis penelitian ini adalah penelitian deskriftip kuantitatif. Dimana hasil penelitian ini menggambarkan hasil perilaku merokok pada mahasiswa FKM yang ada di kampus Banjarbaru. Penelitian ini dilaksanakan dari bulan Oktober-Desember 2018 dan peneltian ini dilakukan di Kampus XXX. Populasi dalam penelitian ini seluruh mahasiswa Fakultas Kesehatan Masyarakat yang ada dikampus XXX berjumlah 120 mahasiswa. sampel dalam penelitian ini menggunakan accidental sampling dengan jumlah sampel 54 mahasiswa. Data yang digunakan ada dua dalam penelitian ini yaitu data primer dan data sekunder. Data primer diperoleh dari hasil wawancara dari informan berupa angket/Kuesioner. Data sekunder diperoleh dari jumlah mahasiswa aktif di Fakultas Kesehatan Masyarakat. Analisis data atau informasi dalam penelitian ini melalui 3 tahapan, tahapan pertama melakukan reduksi data atau merangkum data yang diambil dari hal-hal pokok dari penelitian ini seperti beberapa faktor yang mempengaruhi perilaku merokok yang ada di kalangan mahasiswa FKM. Tahapan kedua penyajian data, data yang sudah diperoleh secara keseluruhan dijabarkan atau dinarasikan oleh peneliti. Dalam penyajian data tentang perilaku merokok yang diperoleh dari hasil pengisian angket dan hasil wawancara pada studi pendahuluan, ada beberapa pengaruh salah satunya kebanyakan dari mencoba-coba dan pengaruh teman sebaya. Tahapan ketiga menarik kesimpulan setelah semua informasi atau data didapat. Setelah data dikumpulkan semua baru di analisis yaitu dari hasil angket/kuesioner dan wawancara. Analisis data dalam penelitian ini dari awal dan akhir penelitian.

\section{HASIL}

Dari penelitian ini didapatkan bahwa distribusi responden menurut usia, sebanyak 14 responden $(25,9 \%)$ usia 18 sampai 20 tahun,sebanyak 3 responden $(5,6 \%)$ usia 17 tahun, 6 responden $(11,1 \%)$ usia 21 tahun, 2 responden $(3,7 \%)$ usia 22 tahun dan 1 responden $(1,9 \%)$ yang usia 24 tahun. distribusi responden menurut semester, sebanyak 27 mahasiswa (50\%) di semester 1, 12 mahasiswa $(22,2 \%)$ di semester 3 dan sebanyak $15(27,8)$ di semester 5 .

Untuk gambaran perilaku mahasiswa dilihat dari tahapan-tahapan perilaku merokok, faktor-faktor penyebab perilaku merokok, aspek dan tipe perilaku merokok. Berdasarkan hasil penelitian di 
FKM , menunjukkan bahwa tahapan-tahapan perilaku merokok yang di awali dari tahapan Preparation berupa tahap keinginan rasa tahu terhadap rokok, dilihat dari umur mulai merokok dan alasan pertama kali merokok. Hasil analisis data diperoleh dari 54 responden umur mulai merokok ada yang dari usia dibawah 10 tahun sebanyak 8 responden dan yang usia diatas 10 tahun sebanyak 35 responden dan sisanya 11 responden tidak menjawab pertanyaan. Adapun alasan pertama kali merokok yang paling dominan dari jawaban responden adalah penasaran atau coba-coba dan ada juga yang menjawab karena iseng, dipaksa temen, bosan dan dianggap keren.Yang kedua tahap initiation tahap kedua ini memutuskan untuk melanjutkan perilaku merokoknya. Dalam tahap ini dapat dilihat dari masih atau tidaknya responden merokok. Dari hasil analisis data sebanyak 46 responden berhenti atau tidak melanjutkan untuk merokok dan 8 responden yang tetap atau masih melajutkan merokoknya. Alasan berhenti merokok karena atas kesadaran sendiri, sakit dan dilarang orang tua ataupun keluarga. Tahap ketiga tahap Becoming a Smoker tahapan ini mengetahui perilaku jumlah batang rokok yang diisap perhari. Dilihat dari hasil analisis data sebanyak 19 responden yang jumlah batang rokoknya perhari 1-10 batang, 4 batang sebanyak 1 responden, 1-7 batang ada 9 responden, 11- 20 batang 2 responden, 1 batang ada 8 responden dan 15 responden tidak menjawab pertanyaan dan tahap terakhir yaitu Tahap Maintenance of
Smoking Tahapan terakhir ini menjelaskan bahwa perilaku merokok yang dilakukannya untuk memperoleh ketenangan. Hasil dari analisis data dari 54 responden keadaan yang membuat untuk merokok kebanyakan coping stres. Selebihnya karena bosan dan iseng.

Hasil penelitian dilihat dari AspekAspek Perilaku Merokok, responden melakukan perilaku merokoknya ada didalam rumah maupun diluar rumah seperti : di tempat teman, dikos, dihutan, ditempat umum, lapangan dll.dilihat dari hasil analisis data yang paling banyak perilaku merokoknya di tempat temen 24 responden, dan didalam rumah sebanyak 7 responden. Waktu merokok adalah kapan (pada momen-momen apa saja) individu melakukan aktivitas merokoknya.Waktu merokok pada saat keadaan lagi hari dingin, broken home dan stres. Seseorang yang merokok dengan jumlah batang rokok yang diisap setiap hari. Dari hasil analisis data sebanyak 23 responden yang mengisap rokok 5-10 batang perhari, 2 responden 1120 batang perhari dan 14 responden 1-4 batang perhari.

Hasil penelitian berdasarkan TipeTipe Perokok tipe perokok ringan, merokok 1-10 batang sehari, Perokok sedang, merokok 11-20 batang sehari, dan Perokok berat, merokok lebih dari 24 batang sehari. Dari hasil analisis data sebanyak 2 responden yang dikategorikan masuk dalam perokok sedang dan 37 responden perokok ringan. Dari hasil penelitian berdasarkan Faktor-faktor Yang Mempengaruhi Perilaku Merokok, menunjukkan Pengaruh orang 
tua, keluarga merupakan lingkungan yag paling dekat, pengaruh untuk seseorang merokok apabila dalam sebuah keluarga ada perokok aktif, baik ayah atau paman. Dari hasil analisis data dari jumlah responden sebanyak 54 ada 7 responden yang perilaku merokok di pengaruhi oleh orang tua dengan diberikan jatah khusus untuk membeli rokok. Dan tindakan orang tua pun hanya membiarkan anaknya merokok. 47 responden tidak terpengaruh. Pengaruh Teman, berbagai fakta mengungkapkan semakin banyak individu merokok maka semakin banyak temanteman individu itu yang merokok, begitu pula sebaliknya. Dari hasil analisis data sebanyak 54 responden, 38 responden perilaku merokok dipengaruhi oleh teman. Dan tindakan teman tidak peduli atau cuek apabila kita merokok. pengaruh iklan, Melihat iklan di media massa dan elektronik yang menampilkan gambaran bahwa perokok adalah lambang kejantanan atau glamour membuat seseorang seringkali terpicu untuk mengikuti perilaku yang ada di iklan tersebut. Berdasarkan hasil analisis data sebanyak 16 responden yang menyatakan pengaruh iklan biasa saja, 7 responden menyatakan pengaruh iklan besar sekali dan 8 responden menyatakan tidak terpengaruh iklan.

\section{PEMBAHASAN}

Tahapan-Tahapan Perilaku Merokok Menurut Leventhal \& Cleary (1980 $)^{4}$ terdapat 4 tahap dalam perilaku merokok sehingga seorang individu benar-benar menjadi perokok, yaitu: tahap pertama, tahap preparation tahap ini berupa tahap keinginan rasa tahu terhadap rokok, dilihat dari umur mulai merokok dan alasan pertama kali merokok. Hasil analisis data diperoleh dari 54 responden umur mulai merokok ada yang dari usia dibawah 10 tahun sebanyak 8 responden dan yang usia diatas 10 tahun sebanyak 35 responden dan sisanya 11 responden tidak menjawab pertanyaan. Penelitia ini agak berbeda dengan penelitian Salawati dan Amalia (2010) ${ }^{5}$, Mengenai waktu pertama kali merokok hampir semua informan mengaku telah merokok sejak SMP dan SMA. Hal ini sesuai dengan beberapa hasil penelitian di Indonesia yang menunjukkan bahwa kebiasaan merokok telah dimulai sejak remaja. Adapun alasan pertama kali merokok yang paling dominan dari jawaban responden adalah penasaran atau coba-coba dan ada juga yang menjawab karena iseng, dipaksa temen, bosan dan dianggap keren. Penelitian ini sejalan dengan penelitian Kalemben (2016), dari hasil penelitiannya dengan wawancara beberapa responden pertama kali merokok dengan alasan coba-coba dan penasaran. Tahap kedua tahap Initiation ini memutuskan untuk melanjutkan perilaku merokoknya. Dalam tahap ini dapat dilihat dari masih atau tidaknya responden merokok. Dari hasil analisis data sebanyak 46 responden berhenti atau tidak melanjutkan untuk merokok dan 8 responden yang tetap atau masih melajutkan merokoknya. Alasan berhenti merokok karena atas kesadaran sendiri, sakit dan 
dilarang orang tua ataupun keluarga. Ketiga, Tahap Becoming a Smoker tahapan ini mengetahui perilaku jumlah batang rokok yang diisap perhari. Dilihat dari hasil analisis data sebanyak 19 responden yang jumlah batang rokoknya perhari 1-10 batang, 4 batang sebanyak 1 responden, 1-7 batang ada 9 responden, 11- 20 batang 2 responden, 1 batang ada 8 responden dan 15 responden tidak menjawab pertanyaan. Penelitian ini tidak sejalan dengan penelitian Salawati dan Amalia $(2010)^{5}$, Hampir semua informan mengaku rata-rata menghabiskan setengah sampai satu bungkus rokok setiap harinya. Apabila sedang menghadapi masalah, tugas, atau sedang merasa enak, beberapa informan mengaku bisa menghabiskan lebih dari biasanya. Namun ada pula informan yang mengaku sehari-hari rata-rata menghisap satu bungkus rokok, baik sedang menghadapi masalah atau tidak. Tahapan terakhir, tahap Maintenance of Smoking ini menjelaskan bahwa perilaku merokok yang dilakukannya untuk memperoleh ketenangan atau kenikmatan. Hasil dari analisis data dari 54 responden keadaan yang membuat untuk merokok kebanyakan coping stres. Selebihnya karena bosan dan iseng. Hasil penelitian ini sejalan dengan penelitian Salawati dan Amalia (2010) ${ }^{5}$, Sebagian besar informan meyakini bahwa merokok itu nikmat. Diantara informan yang meyakini bahwa merokok itu nikmat, sebagian mengaku merasakan nikmatnya merokok setelah makan, dan sebagian lagi mengaku merasakan kenikmatan merokok ketika sedang sendirian. Bahkan ada seorang informan yang mengaku merasakan nikmatnya merokok saat buang air besar, dan ada pula seorang informan yang merasakan nikmatnya merokok, hingga dirinya merasakan bahwa merokok membuat dirinya tidak lapar. Hasil penelitian ini juga searah dengan penelitian Srisatyorini (2004) ${ }^{7}$ dimana hampir semua informan menyatakan bahwa merokok dapat menimbulkan ketenangan dan hidup terasa tanpa beban dan informan yakin bahwa ketenangan yang dirasakan disebabkan oleh rokok yang mereka hisap.

Aspek-aspek perilaku merokok dapat dilihat dari, tempat merokok, Responden melakukan perilaku merokoknya ada didalam rumah maupun diluar rumah seperti : di tempat teman, dikos, dihutan, ditempat umum, lapangan dll.dilihat dari hasil analisis data yang paling banyak perilaku merokoknya di tempat temen 24 responden, dan didalam rumah sebanyak 7 responden. Penelitian ini sejalan dengan hasil penelitian Kalemben $(2016)^{6}$, dari hasil wawancara dengan responden mereka lebih sering merokok ditempat nongkrong atau sedang berkumpul-kumpul dengan temannya. Tetapi ada juga salah satu responden dari hasil wawancara lebih sering merokok di dalam kamar. Adapula responden yang merokok pada saat bangun pagi, saat sedang lelah dan saat sedang mengerjakan tugas. Informan mengatakan bahwa dia biasanya merokok di kamar/ WC dan ketika bersama teman-temannya dia biasanya merokok di kost-an teman dan juga di café. Waktu merokok adalah kapada 
(pada momen-mome apa saja) individu melakukan aktivitas merokoknya.Waktu merokok pada saat keadaan lagi hari dingin dan stres. Penelitian ini searah dengan penelitian Sumarni $(2015)^{9}$, rata-rata informan memiliki kesamaan dalam tempat merokok yaitu pada saat mereka berkumpul dengan temen-temennya, contoh di kafe dan ketika mereka merasa cuacanya dingin. Intensitas Merokok, Seseorang yang merokok dengan jumlah batang rokok yang diisap setiap hari. Dari hasil analisis data sebanyak 23 responden yang mengisap rokok 5-10 batang perhari, 2 responden 1120 batang perhari dan 14 responden 1-4 batang perhari. Penelitian ini searah dengan penelitian Sumarni $(2015)^{9}$, ada salah satu informan mampu menghabiskan satu bungkus perhari, dan beberapa informan rata-rata menghisap rokok antara 5 hingga 7 batang perhari.

Tipe perokok (Sitepoe dalam Perwitasari, 2006) ${ }^{8}$ yaitu :Perokok ringan, merokok 1-10 batang sehari, Perokok sedang, merokok 11-20 batang sehari, dan Perokok berat, merokok lebih dari 24 batang sehari. Dari hasil analisis data sebanyak 2 responden yang dikategorikan masuk dalam perokok sedang dan 37 responden perokok ringan. Penelitian ini juga searah dengan penelitian kalemben $(2016)^{16}$, Dalam penelitian ini juga dibahas mengenai perokok sosial (social smoker). Dan terkait dengan hal tersebut diketahui bahwa dari 12 orang informan terdapat 3 orang informan yang memenuhi kriteria perokok sosial.
Ketiga informan ini diketahui tidak merokok setiap hari. Adapun jumlah rokok yang dihisap satu informan 3 batang satu kali merokok, satu informan yaitu 4 batang satu kali merokok dan satu informan yaitu 3-4 batang satu kali merokok. Dari hasil penelitian Sumarni $(2015)^{17}$, ada ada salah satu informan masuk dalam kategori perokok berat, dan 3 informan yang masuk dalam kategori perokok sedang.

$$
\text { Mu'tadin (dalam Aula, 2010) }{ }^{10}
$$
mengemukakan alasan seseorang merokok, diantaranya pengaruh orang tua, keluarga merupakan lingkungan yag paling dekat, pengaruh untuk seseorang merokok apabila dalam sebuah keluarga ada perokok aktif, baik ayah atau paman. Dari hasil analisis data dari jumlah responden sebanyak 54 ada 7 responden yang perilaku merokok di pengaruhi oleh orang tua dengan diberikan jatah khusus untuk membeli rokok. Dan tindakan orang tua pun hanya membiarkan anaknya merokok. 47 responden tidak terpengaruh.

Keluarga memiliki peran yang strategis dalam membentuk sikap remaja karena keluarga merupakan tempat pembelajaran pertama seorang remaja (Rachmat, 2013) $)^{11}$. Dalam penelitian Kalemben (2016) ${ }^{6}$. Informan dalam penelitian ini memiliki anggota keluarga yang merokok. Dari jawaban informan diketahui anggota keluarga yang merokok yaitu ayah, ibu, kakak, adik, sepupu, kakek dan tante.Mereka mengetahui bahwa anggota keluarga mereka tersebut merokok 
karena informan sering melihat anggota keluarganya merokok di depannya. Hal ini sejalan dengan penelitian (Rachmat, 2013) ${ }^{11}$ yang mengatakan bahwa perilaku orangtua mendorong perilaku meniru seorang anak (remaja) terhadap orang tua, remaja yang tinggal serumah dengan orangtua yang merokok dan sering melihat mereka merokok, akan melakukan peniruan (imitasi) perilaku merokok. Orang tua menjadi model tingkah laku anak, termasuk perilaku merokoknya.

Dalam hal tindakan orang tua terhadap anaknya yang merokok, hasil penelitian Kalemben $(2016)^{6}$, Dapat diihat dari jawaban informan yang mengatakan bahwa jika dia ketahuan merokok dia pasti akan mendapat teguran dan akan kena marah dari keluarganya.Begitupun halnya dengan informan yang mengatakan bahwa keluarga mereka mengetahui jika mereka merokok, namun meskipun diketahui merokok awalnya mereka kena marah dari keluarga namun karena adanya ketergantungan dari rokok yang sulit dihentikan membuat mereka tetap merokok walaupun dilarang.

Terkait dengan sumber biaya informan untuk membeli rokok, dari hasil penelitian Kalemben $(2016)^{6}$ berdasarkan wawancara diketahui bahwa informan memperoleh rokok dengan membeli sendiri. Adapun sumber biaya informan untuk membeli rokok adalah dengan menggunakan uang jajan yang diberikan oleh orangtua yang mereka sisihkan. Adapula informan yang membeli rokok dengan menggunakan uang hasil kerjanya. Hal ini juga sejalan dengan hasil penelitian Cahyo, dkk (2012) $)^{12}$ yang mengungkapkan bahwa untuk membeli rokok biasanya subyek penelitian (informan) memanfaatkan uang saku dari orang tua atau uang hasil kerjanyanya sendiri.

Berbagai fakta mengungkapkan semakin banyak individu merokok maka semakin banyak teman-teman individu itu yang merokok, begitu pula sebaliknya. Dari hasil analisis data sebanyak 54 responden, 38 responden perilaku merokok dipengaruhi oleh teman. Dan tindakan teman tidak peduli atau cuek apabila kita merokok.Menurut Leventhal dalam Cahyo, dkk (2012) ${ }^{12}$ tekanan dari kelompok teman sebaya merupakan variabel terpenting yang menyebabkan seorang remaja merokok.

Penelitian ini sejalan dengan penelitian Kalemben $(2016)^{6}$, Berdasarkan hasil wawancara diketahui bahwa pengaruh teman sebaya merupakan faktor utama informan merokok. Pada bagian sebelumnya, telah dijelaskan bahwa dari 12 orang informan, terdapat 7 informan yang pertama kali memperoleh informasi tentang rokok dari teman sebaya mereka. Adapun alasan informan pertama kali merokok karena coba-coba bersama teman-teman sepergaulannya. Awalnya mereka melihat teman mereka merokok kemudian mereka mendapat ajakan merokok dari teman. Bermula dari melihat teman yang merokok, mendapat ajakan merokok dari teman akhirnya informan coba-coba dan merokok sampai sekarang. Hal ini sejalan dengan 
Prohaska dan Hirchman dalam Sari (2008) ${ }^{13}$ yang menyatakan bahwa ketika anak muda mencoba rokok pertamanya, mereka biasanya merokok dengan ditemani temantemannya dan dengan dorongan dari temantemannya.

Hal ini sejalan dengan Cahyo, dkk $(2012)^{12}$ yang mengatakan bahwa teman sebaya memberikan pengaruh untuk terus merokok. Hal ini terjadi karena berkumpul dengan teman sebaya sudah menjadi kebiasaan dan telah menjadi gaya hidup bagi remaja sehingga remaja ingin ikut merasakan rokok atau hanya karena merasa tidak enak karena semua temannya merokok.

Melihat iklan di media massa dan elektronik yang menampilkan gambaran bahwa perokok adalah lambang kejantanan atau glamour membuat seseorang seringkali terpicu untuk mengikuti perilaku yang ada di iklan tersebut. Berdasarkan hasil analisis data sebanyak 16 responden yang menyatakan pengaruh iklan biasa saja, 7 responden menyatakan pengaruh iklan besar sekali dan 8 responden menyatakan tidak terpengaruh iklan.

Perilaku tertentu dapat terbentuk salah satunya dipengaruhi oleh karena adanya faktor yang memungkinkan/ memfasilitasi terjadinya perilaku tersebut (Notoadmodjo, 2010) ${ }^{14}$. Dalam penelitian ini, iklan rokok merupakan faktor pemungkin yang dikaji oleh peneliti untuk melihat pengaruhnya terhadap perilaku merokok informan.
Dalam penelitian Kalemben (2016) ${ }^{6}$, Iklan rokok sebagaimana diketahui merupakan media yang penting dalam memperoleh informasi seputar rokok. Iklan merupakan media promosi yang sangat ampuh dalam membentuk opini publik di bidang rokok. Iklan-iklan rokok juga dapat dijumpai di mana saja, mulai dari Buildboard, spanduk, umbul-umbul, iklan di media cetak ataupun elektronik (Ninu, Zemida,dkk,2013) $)^{14}$.Berdasarkan hasil wawancara yang telah dilakukan informan mengatakan pernah melihat/ mendengar iklan tentang rokok, bahkan ada yang setiap hari melihat iklan rokoktersebut. Dari hasil wawancara informan mengatakan pernah melihat/mendengar iklan tentang rokok di TV dan di pamflet-pamflet atau balihobaliho yang ada di jalan. Adapula informan yang pernah melihat/ mendengar iklan tentang rokok di surat kabar dan di radio.

\section{KESIMPULAN DAN SARAN}

Kesimpulan dari penelitian ini adalah alasan pertama kali merokok responden yang paling dominan adalah penasaran atau coba-coba, lebih dari separo responden perilaku merokoknya masuk dalam tipe perokok ringan. Dan dari 54 responden sebanyak 38 responden faktor yang mempengaruhi merokok adalah pengaruh dari teman. Bagi Wali Kota Banjarbaru agar ada penerapan kawasan tanpa rokok di wilayah kota Banjarbaru dengan ditambah Peraturan Daerah. Bagi Dinas Kesehatan dan Puskesmas agar selalu memberikan edukasi terhadap masyarakat 
tentang bahaya merokok. Bagi Universitas dan Fakultas agar ada penerapan dan pemberian edukasi kepada seluruh mahasiswa/i tentang bahaya merokok atau larangan merokok dilingkungan kampus. Bagi Peneliti Selanjutnya disarankan agar untuk memperdalam lagi penelitian ini dengan menambahkan beberapa Variabel atau diubah menjadi penelitian kuantitatif.

\section{DAFTAR PUSTAKA}

1. Wartonah, Tarwoto. Kebutuhan Dasar manusia dan Proses Keperawatan. Jakarta : Salemba Medika; 2010.

2. Kemenkes RI. Riset Kesehatan Dasar (RISKESDAS). Jakarta: Balitbang; 2013.

3. Wismanto, Y Bagusdan Y Budi Sarwo. Strategi Penghentian Perilaku Merokok. Semarang: Unika Soegijapranata; 2007. [Diakses pada tanggal 12 September 2018]. Available at:

http://eprints.unika.ac.id/236/1/Strahen _Prilaku_Mrokok.pdf.

4. Leventhal, Howard \& Cleary, Paul D. The Smoking Problem: A Review of the Research and Theory in Behavioral Risk Modification. Psychological Bulletin. 1980; 80(2): 370-405.

5. Salawati, Trixie dan Rizka Amalia. Perilaku Merokok Dikalangan Mahasiswa Universitas Muhammadiyah Semarang (Smoking Behaviour Among Student in UNIMUS). Prosiding Seminar Nasional Universitas

\section{UCAPAN DAN TERIMA KASIH}

Ucapan terima kasih disampaikan kepada kampus Uniska MAB Banjarmasin yang telah mendanai penelitian ini, yang kedua ke Kampus XXX yang telah memberikan ijin penelitian di Fakultas Kesehatan Masyarakat, dan yang ketiga kepada teman-teman Tim Peneliti yang telah membuat penelitian ini.

Muhammadiyah Semarang. 2010.

Diakses 26 Februari 2019

6. Kalemben, Sartika. 2016. Perilaku

Merokok Pada Mahasiswi di Universitas Hasanuddin Makassar.

Skripsi, Departemen Promosi

Kesehatan, Fakultas Kesehatan

Masyarakat, Universitas Hasanuddin Makassar; 2016.

7. Srisantyorini, Triana, dan F. Y. Sumartin. Perilaku Merokok

Mahasiswa Universitas Muhammadiyah Jakarta dan Faktor- Faktor yang Mempengaruhinya Tahun 2004, Jurnal Kedokteran dan kesehatan UMJ. Juli 2005: 1(2) ISSN 02163942.

8. Sitoepo,dkk. Kekhususan Rokok Indonesia. Jakarta: Grasindo; 2009.

9. Sumarni,Ayik. Gambaran Perilaku Merokok pada Mahasiswi Universitas Kristen Satyawacana. 2015. [Diakses: 12 September 2018]. Available at: http://repository.uksw.edu/bitstream/12 3456789/8966/2/T1_802009107_Full\% 20text.pdf. Skripsi. 
10. Mu'tadin. Kemandirian Sebagai Kebutuhan Psikologis Pada Remaja.Jakarta : Rineka Cipta; 2005.

11. Rachmat, Thaha \& Syafar. Perilaku Merokok Remaja Sekolah Menengah Pertama. Jurnal Kesehatan Masyarakat Nasional. 2013: 7(11).

12. Cahyo, Kusyogo, dkk. Rokok, Pola Pemasaran dan Perilaku Merokok Siswa SMA/Sederajat di Kota Semarang. Jurnal Media Kesehatan Masyarakat Indonesia. 2012: 11(1).
13. Sari, Dian Puspita. Kebiasaan Merokok Remaja Putri. Semarang: Universitas Negeri Semarang; 2012.

14. Notoatmodjo, Soekidjo. Promosi Kesehatan Teori Dan Aplikasi. Jakarta: Rineka Cipta; 2010.

15. Ninu, Zemida, dkk. Peran Iklan Rokok dan Teman Sebaya Dalam Mempengaruhi Perilaku Merokok Pada Remaja di SMA PGRI Kupang. Jurnal MKM; 2013: 08(01) Desember 2013. 


\section{LAMPIRAN}

\section{Dsitribusi Responden Menurut Usia}

Tabel 1. Distribusi Responden Berdasarkan Usia Mahasiswa Fakultas Kesehatan Masyarakat di Kampus XXX

\begin{tabular}{ccc}
\hline Usia & f & \% \\
\hline 17 Tahun & 3 & 5,6 \\
18 Tahun & 14 & 25,9 \\
19 Tahun & 14 & 25,9 \\
20 Tahun & 14 & 25,9 \\
21 Tahun & 6 & 11,1 \\
22 Tahun & 2 & 3,7 \\
24 Tahun & 1 & 1,9 \\
Jumlah & 54 & 100 \\
\hline
\end{tabular}

Sumber : Data Primer, 2019

\section{Distribusi Responden Menurut Semester}

Tabel 2. Distribusi Responden Berdasarkan Semester Mahasiswa Fakultas

\begin{tabular}{ccc}
\multicolumn{3}{c}{ Kesehatan Masyarakat di Kampus XXX } \\
\hline Semester & F & \% \\
\hline 1 & 27 & 50,0 \\
3 & 12 & 22,2 \\
5 & 15 & 27,8 \\
Jumlah & 54 & 100 \\
\hline
\end{tabular}

Sumber : Data Primer, 2019

3. Umur Responden Mulai Merokok

Tabel 3. Umur Mulai Merokok Mahasiswa Fakultas Kesehatan Masyarakat di Kampus XXX

\begin{tabular}{ccc}
\hline Umur Mulai Merokok & f & \% \\
\hline Lebih dari 10 Tahun & 35 & 64,8 \\
Kurang dari 10 Tahun & 8 & 14,8 \\
Tidak Sama Sekali & 11 & 20,4 \\
Jumlah & 54 & 100
\end{tabular}

Sumber : Data Primer, 2019 


\section{Alasan Responden Pertama Kali Merokok}

Tabel 4. Alasan Pertama Kali Merokok Mahasiswa Fakultas Kesehatan Masyarakat di Kampus XXX

\begin{tabular}{lcc}
\hline \multicolumn{1}{c}{ Alasan Pertama Kali Merokok } & f & \% \\
\hline Bosan & 1 & 1,9 \\
Dewasa/Keren & 2 & 3,7 \\
Diajak/dipaksa Temen & 2 & 3,7 \\
Iseng & 8 & 14,8 \\
Menambah Pajak Negara & 1 & 1,9 \\
Penasaran/Coba-coba & 26 & 48,1 \\
Tidak Sama Sekali & 14 & 25,9 \\
Jumlah & 54 & 100 \\
\hline
\end{tabular}

Sumber : Data Primer, 2019

5. Alasan Berhenti Merokok

Tabel 5. Gambaran Alasan Berhenti Merokok Mahasiswa

Fakultas Kesehatan Masyarakat di Kampus XXX

\begin{tabular}{ccc}
\hline Alasan Berhenti Merokok & f & \% \\
\hline Atas Kesadaran Sendiri & 43 & 79,3 \\
Bosan & 1 & 1,9 \\
Dalam Proses & 1 & 1,9 \\
Dilarang orang tua/keluarga & 3 & 5,6 \\
Rasa rokok biasa & 1 & 1,9 \\
Sakit & 3 & 5,6 \\
Terpengaruh & 1 & 1,9 \\
Tidak Nyaman Merokok & 1 & 1,9 \\
Jumlah & 54 & 100 \\
\hline
\end{tabular}

Sumber : Data Primer, 2019

\section{Jumlah Batang Merokok Per hari}

Tabel 6. Jumlah Batang Merokok Perhari Mahasiswa Fakultas Kesehatan Masyarakat di Kampus XXX

\begin{tabular}{ccc}
\hline Kebiasaan Merokok & F & \% \\
\hline 1 Batang & 8 & 14,8 \\
1-2 Batang & 1 & 1,9 \\
1-3 Batang & 2 & 3,7 \\
1-4 Batang & 2 & 3,7 \\
1-5 Batang & 2 & 3,7 \\
1-7 Batang & 2 & 3,7 \\
1-10 Batang & 19 & 35,1 \\
11-20 Batang & 2 & 3,7 \\
\hline
\end{tabular}




\begin{tabular}{ccc}
\hline 4 Batang & 1 & 1,9 \\
Tidak Merokok & 15 & 27,8 \\
Jumlah & 54 & 100 \\
\hline
\end{tabular}

Sumber : Data Primer, 2019

\section{Keadaan Merokok}

Tabel 7. Keadaan Merokok Mahasiswa

Fakultas Kesehatan Masyarakat di Kampus XXX

\begin{tabular}{ccc}
\hline Keadaan Merokok & f & \% \\
\hline Bosan & 10 & 18,5 \\
Broken Home & 1 & 1,9 \\
Coba-coba & 1 & 1,9 \\
Ditawarkan Teman & 1 & 1,9 \\
Gugup & 1 & 1,9 \\
Hari Dingin & 1 & 1,9 \\
Melihat Orang Merokok & 2 & 3,7 \\
Paksaan & 1 & 1,9 \\
Santai/Iseng & 10 & 18,5 \\
Stres & 14 & 25,8 \\
Tidak & 12 & 22,1 \\
Jumlah & 54 & 100 \\
\hline
\end{tabular}

Sumber : Data Primer, 2019

\section{Tempat Kebiasaan Merokok}

Tabel 8. Tempat Kebiasaan Merokok Mahasiswa Fakultas Kesehatan Masyarakat di Kampus XXX

\begin{tabular}{ccc}
\hline Kebiasaan Merokok & F & \% \\
\hline Di Kos & 1 & 1,9 \\
Di Hutan & 1 & 1,9 \\
Di Rumah & 7 & 13,0 \\
Di Tempat Pribadi & 1 & 1,9 \\
Di Tempat Teman & 24 & 44,3 \\
Lapangan & 1 & 1,9 \\
Ruangan Khusus & 1 & 1,9 \\
Sembunyi & 2 & 3,6 \\
Tidak Merokok & 13 & 24,0 \\
Umum & 3 & 5,6 \\
Jumlah & 54 & 100 \\
\hline
\end{tabular}

Sumber : Data Primer, 2019 
9. Merokok Bersama Keluarga

Tabel 9. Merokok Bersama Keluarga Mahasiswa Fakultas Kesehatan Masyarakat di Kampus XXX

\begin{tabular}{ccc}
\hline $\begin{array}{c}\text { Merokok Bersama } \\
\text { Keluarga }\end{array}$ & f & \% \\
\hline Pernah & 7 & 13,0 \\
Tidak & 47 & 87,0 \\
Jumlah & 54 & 100 \\
\hline
\end{tabular}

Sumber : Data Primer, 2019

10. Tindakan Keluarga Ketika Merokok

Tabel 10. Tindakan Keluarga Ketika Merokok Mahasiswa Fakultas Kesehatan Masyarakat di Kampus XXX

\begin{tabular}{ccc}
\hline $\begin{array}{c}\text { Tindakan Keluarga } \\
\text { Ketika Merokok }\end{array}$ & $\mathbf{f}$ & \% \\
\hline Ditegur & 36 & 66,7 \\
Dibiarkan & 18 & 33,3 \\
Jumlah & 54 & 100 \\
\hline
\end{tabular}

Sumber : Data Primer, 2019

11. Orang Tua Memberikan Jatah Membeli Rokok

Tabel 11. Orang Tua Memberikan Jatah Membeli Rokok Mahasiswa Fakultas Kesehatan Masyarakat di Kampus XXX

\begin{tabular}{ccc}
\hline $\begin{array}{c}\text { Orang Tua Memberikan } \\
\text { Jatah Membeli Rokok }\end{array}$ & f & \% \\
\hline Pernah & 3 & 5,6 \\
Tidak & 51 & 94,4 \\
Jumlah & 54 & 100 \\
\hline
\end{tabular}

Sumber : Data Primer, 2019 
12. Merokok Bersama Teman

Tabel 12. Merokok Bersama Teman Mahasiswa Fakultas Kesehatan Masyarakat di Kampus XXX

\begin{tabular}{ccc}
\hline $\begin{array}{c}\text { Merokok Bersama } \\
\text { Teman }\end{array}$ & f & \% \\
\hline Pernah & 38 & 70,4 \\
Tidak & 16 & 29,6 \\
Jumlah & 54 & 100 \\
\hline
\end{tabular}

Sumber : Data Primer, 2019

13. Tindakan Teman Ketika Merokok

Tabel 13. Tindakan Teman Ketika Merokok Mahasiswa Fakultas Kesehatan Masyarakat di Kampus XXX

\begin{tabular}{cccc} 
& Tindakan Teman Ketika Merokok & F & \% \\
\cline { 2 - 4 } & Biasa Saja & 1 & 1,9 \\
& Ikut-ikutan Merokok & 3 & 5,6 \\
& Meminta Rokok & 6 & 11,1 \\
& Senasehati/menegur & 7 & 13,0 \\
umber & Menghindari/menjauh & 3 & 5,6 \\
: Data & Tidak Peduli/cuek & 34 & 62,8 \\
Prime & Jumlah & 54 & 100 \\
\hline
\end{tabular}

r, 2019

14. Pengaruh Iklan Untuk Merokok

Tabel 14. Pengaruh Iklan Untuk Merokok Mahasiswa Fakultas Kesehatan Masyarakat di Kampus XXX

\begin{tabular}{ccc}
\hline Pengaruh Iklan Untuk Merokok & f & \% \\
\hline Besar & 5 & 9,3 \\
Besar Sekali & 7 & 13,0 \\
Biasa Saja & 16 & 29,6 \\
Sangat Tidak Berpengaruh & 8 & 14,8 \\
Tidak ada & 18 & 33,3 \\
\hline
\end{tabular}


Sumber : Data Primer, 2019 